International Journal of
For
Food
Sciences
(IJF)

IMPLEMENTING THE HACCP CONCEPT IN NIGERIAN TONGUE SOLE FISH (Cynoglossus browni) FILLETS AND MINCE PRODUCTION IN A FISH PROCESSING PLANT FOR EXPORT.

Oluwafemi, Paul Fajana and Gabriel Mekuleyi

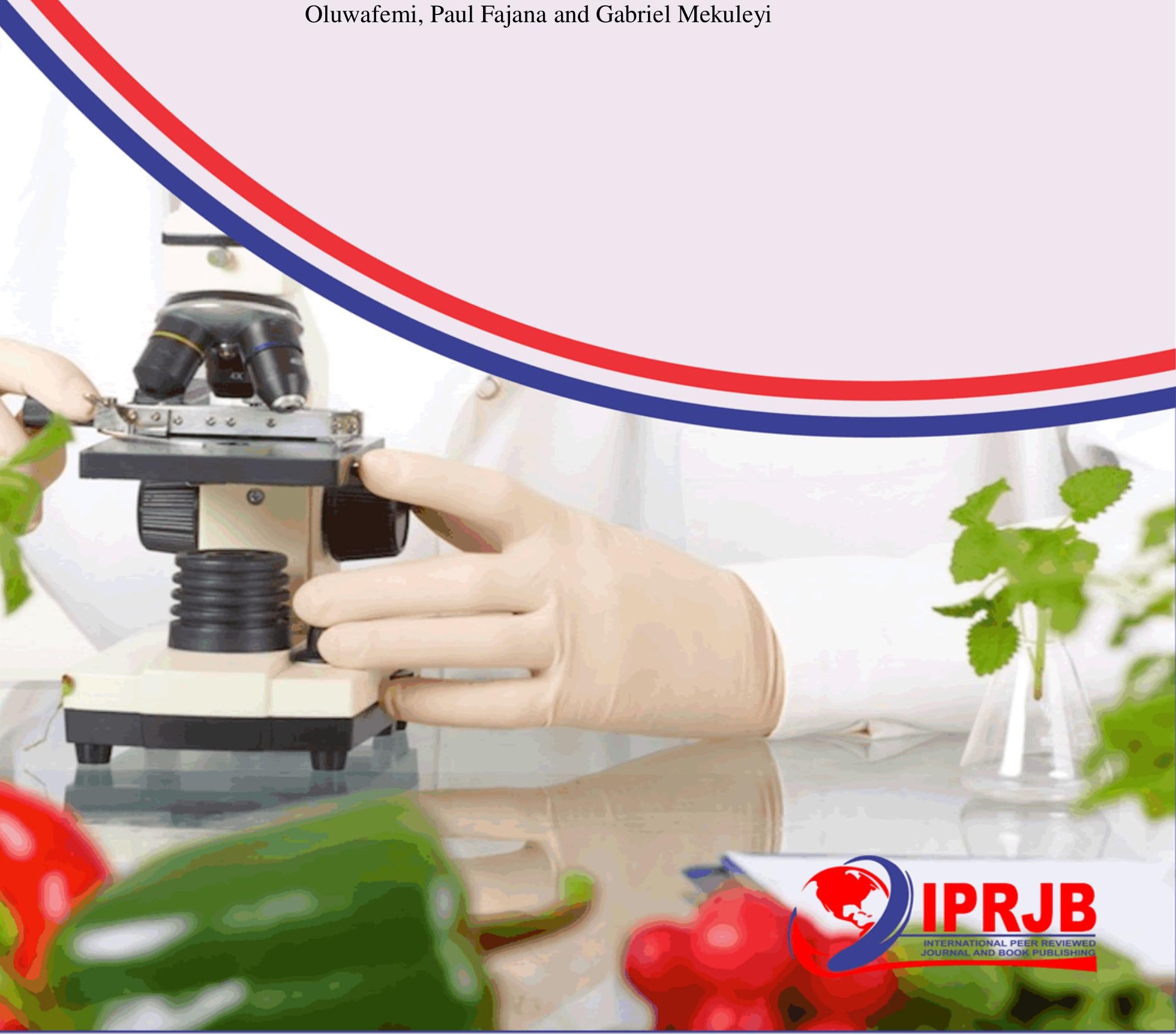




\title{
IMPLEMENTING THE HACCP CONCEPT IN NIGERIAN TONGUE SOLE FISH (Cynoglossus browni) FILLETS AND MINCE PRODUCTION IN A FISH PROCESSING PLANT FOR EXPORT.
}

\author{
$1^{*}$ Oluwafemi, Paul Fajana \\ Masters Student: Department of Fisheries;Lagos State University, Ojo, Lagos, Nigeria. \\ *Corresponding Author's Email: polofemo@gmail.com \\ ${ }^{2}$ Gabriel Mekuleyi \\ Lecturer, Department of Fisheries: Lagos State University, Ojo, Lagos, Nigeria
}

\begin{abstract}
Purpose: This study was carried out in the Fish processing plant of Olokun Pisces Limited from June November, 2018 with the primary focus on implementing Hazard Analysis Critical Control Point (HACCP) concept as a tool to ensure safety of food products. Sole fish Fillets and Mince were produced from mechanized raw processing of Nigerian tongue Sole fish (Cynoglossus browni) using the knowledge of HACCP application.

Methods: The Processing Plant is owned by Olokun Pisces Limited (Lat N $6^{0} 28^{1} 24^{11}$, Long E $3^{0} 22^{1} 50^{11}$ ), a Private Fishing Company located in Otto, Lagos, Nigeria. The Company has over thirty trawlers licensed by the Federal Department of Fisheries (FDF) to fish in Nigerian Coastal waters which falls within Eastern Central Atlantic FAO Area 34. The Nigerian coastal line has eight states it shares borders with. They are Lagos, Ogun, Ondo, Rivers, Delta, Akwa Ibom, Bayelsa and Cross River States. A trawler voyage of about fifty (50) days to and fro covers the coastal waters including the eight coastal states. The study was carried out from June - November, 2018. On board frozen Cynoglossus browni is being received in bags (20kg net weight) from the trawler vessels upon arrival and stored in the cold room (with a temperature of $-20^{\circ} \mathrm{C}$ ) prior to processing. Cynoglossus browni being a demersal species was caught by method of bottom trawling.

Results: The HACCP concept focused on the safety of sole fish fillets and mince through a systematic and scientific approach to hazard identification, assessment and control. Preventive and control measures in dealing with identified hazards helps to eliminate or reduce hazards to acceptable levels. Pre-requisite programs consolidate the effectiveness of the HACCP in achieving safety of food products. The verification exercise confirmed that the HACCP concept implemented in the processing of Sole fish fillets and mince was adhered to and the products are safe, fit for consumption and ready for export.

Unique contribution to theory, practice and policy:To achieve safety of food products requires the joint effort of the HACCP team. Hence, adequate training of the team members on recent developments and changes in the food industry is very key to consistently improve efforts to always maintain the quality brand the product is known for.
\end{abstract}

Keywords: Hazard, Safety, HACCP Plan, Preventive measures 


\subsection{INTRODUCTION}

The HACCP concept was introduced in the United States in 1971 at the Conference of Food Protection where it was "recommended for widespread use". During the initial period of space exploitation preparation by NASA, it was recognized that absolutely safe food was required for the astronauts. Collaboration by the Pillsbury Company, NASA and the US Army Laboratories proposed HACCP that was based on the Failure, Mode and Effect Analysis (FMEA) as used by engineers in construction designs. In general the US food industry showed little interest, but microbiological problems with low-acid can foods, particularly mushrooms, led to the FDA promulgating specific regulations for control embodying HACCP Principles. Their successful introduction in the canning industry inevitably led to pressure for their wider acceptance by the food industry. Subsequently, as a means of safe food production, it has been adopted world-wide as given in Codex Alimentarius Commission. In European Union Legislative Framework, HACCP Concept was introduced by the EU Food Hygiene Directive 93/43/EEC that was repealed by Regulation (EC) 852/2004 on the hygiene of food stuffs as a tool to ensure food safety (Georgia and Fotoula, 2010). What is HACCP (Hazard Analysis Critical Control Point)? It is a science based system which identifies, evaluates and controls hazards which are significant for food safety. HACCP is a tool used to assess hazards and establish control systems that focus on prevention rather than relying mainly on end-product testing. Any HACCP system is capable of accommodating change such as advances in equipment design, processing procedures or technological developments.

The HACCP is based on the recognition that hazards exist at various points but measures can be taken to control these hazards. The anticipation of hazard, identification of control points, implementation of corrective actions when the critical limits are exceeded and a comprehensive record keeping are some of the key elements to HACCP. The system offers a rational, practical and logical approach in the control of food hazards and avoids the many weaknesses inherent in the conventional approach. Once established, the main effort of the Quality Assurance programme will be directed towards Critical Control Points and away from endless final product testing. This will assure a higher degree of safety and at less cost. HACCP can be applied throughout the food chain from primary production to final consumption and its implementation should be guided by scientific evidence of risks to human health.

\section{DEFINITIONS}

HAZARD: A biological, chemical or physical agent in, or condition of food with the potential to cause an adverse health effect.

HACCP Plan: A document prepared in accordance with the principles of HACCP to ensure control of hazards which are significant for food safety in the segment of the food chain under consideration.

CRITICAL LIMIT: A criterion which separates acceptability from unacceptability.

CRITICAL CONTROL POINT (CCP): A step at which control can be applied and is essential to prevent or eliminate a food safety hazard or reduce it to an acceptable level.

CORRECTIVE ACTION: Any action to be taken when the results of monitoring at the CCP indicate a loss of control

CONTROL MEASURE: Any action and activity that can be used to prevent or eliminate a food safety hazard or reduce it to an acceptable level.

MONITOR: The act of conducting a planned sequence of observations or measurements of control parameters to assess whether a CCP is under control. 
International Journal of Food Science

Vol.2, Issue 1. No.1, pp 1- 16, 2019

VERIFICATION: The application of methods, procedures, tests and other evaluations in addition to monitoring, to determine compliance with the HACCP plan. (FAO, 1997)

\section{SEVEN PRINCIPLES OF HACCP}

Principle 1 Hazard Analysis

Principle 2 Determine the Critical Control Points (CCP)

Principle 3 Establish Critical limit(s)

Principle 4 Monitoring

Principle 5 Corrective Action

Principle 6 Verification

Principle 7 Documentation

\section{APPLICATION OF HACCP}

1. Assemble HACCP Team

2. Describe product

3. Identify intended use

4. Construct flow diagram

5. On-site confirmation of flow diagram

6. 7 principles of HACCP

Cynoglossus browni Chabanand, 1949 commonly called Nigerian tongue sole fish has an elongated body, snout rounded with a short rostal hook not reaching to vertical through front margin of upper eye; eyes on left side, small with a broad space between them. Maxilla reading back behind upper eye. Dorsal fin rays 115 - 15; anal fin rays 96 - 99; candal fin rays 12. Eyed side with 2 lateral lines, the midlateral with $84-91$ scales; scales ctenoid on eyed side, cycloid on blind side. It has eyed side dark brown with a whitish blind side and size could be up to $40 \mathrm{~cm}$. Its habitat is benthic on muddy or sandy bottoms of the continental shelf, at depths of $15-40$, (mainly $15-25 \mathrm{~m}$ ). It feeds on a wide range of bottom living invertebrates. It is distributed in West Africa (Congo to Senegal) as well as from the Netherlands Coast (Marine Species Identification Portal, 2018)

\section{Objectives}

1. To apply the HACCP concept in a mechanized Sole fish fillets and mince production process in order to achieve safety of the products

2. To meet the requirements and standards acceptable for export to sophisticated international market such as the EU and the United States using the HACCP concept.

\subsection{MATERIALS AND METHODS}

\section{The Study Area}

The Processing Plant is owned by Olokun Pisces Limited (Lat N $6^{0} 28^{1} 24^{11}$, Long E $3^{0} 22^{1} 50^{11}$ ), a Private Fishing Company located in Otto, Lagos, Nigeria. The Company has over thirty trawlers licensed by the Federal Department of Fisheries (FDF) to fish in Nigerian Coastal waters which falls within Eastern Central Atlantic FAO Area 34. The Nigerian coastal line has eight states it shares borders with. They are Lagos, Ogun, Ondo, Rivers, Delta, Akwa Ibom, Bayelsa and Cross River States. A trawler voyage of 
about fifty (50) days to and fro covers the coastal waters including the eight coastal states. The study was carried out from June - November, 2018.

\section{Pre-Requisite Programs}

In order to consolidate the HACCP concept, strong foundational programs are expected to be in place to address basic operational and sanitation procedures. Some of these that were put in place include Good Manufacturing Practices (GMP), Personnel hygiene program, Standard Sanitary Operating Procedures (SSOP), Pesticides (SMASH SUPER 100\% EC) and general fumigation program, first-in first-out (FIFO), Employee training exercise, Medical examination, etc. All these programs were done and documented before executing the HACCP plan.

\section{Collection of Raw Materials}

On board frozen Cynoglossus browni is being received in bags (20kg net weight) from the trawler vessels upon arrival and stored in the cold room (with a temperature of $-20^{\circ} \mathrm{C}$ ) prior to processing. Cynoglossus browni being a demersal species was caught by method of bottom trawling.

\section{Application of HACCP in Sole fish fillets and mince production}

The HACCP system was implemented on the twelve steps given by Codex Alimentarius Commission mention as follows 
International Journal of Food Science

Vol.2, Issue 1. No.1, pp 1- 16, 2019

Assemble the $\Downarrow$ ACCP Team

Describe Product

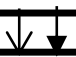

Identify Intended Use

$\checkmark$

Construct Flow Diagram

$\downarrow$

On-site Verification of Flow Diagram

List all Potential Hazards,

Conduct a Hazard Analysis,

Determine Control Measures

$\downarrow$

Determine CCPs

$\checkmark$

Establish Critical Limit for Each CCP

$\sqrt{ }$

Establish a Monitoring System for Each CCP

$\sqrt{ }$

Establish Corrective Action for Deviations that may occur

$\sqrt{ }$

Establish Verification Procedures

Establish Record Keeping and Documentation

Figure 1: Logical Sequence for the Application of HACCP

Assemble the HACCP team: The first task in the application of HACCP in Sole fish fillets and Mince production was to create a team having the knowledge and expertise to develop a HACCP plan. The team formed was multidisciplinary led by the Quality Control Manager to include Microbiologists, Biochemist, Fisheries Scientists, Quality Assurance personnel, Production supervisors, Engineers, Sanitary personnel, Processing plant personnel and Management staff. The team members had clearly and well defined roles in the production process. 
Describe the product: The HACCP Team made a complete description of the product on the basis of raw material (Nigerian Tongue Sole fish), origin, storage temperature and nutritional information as shown in Table 1.

Identify intended use: Intended use was identified based on the normal use of the end consumer. Sole Fish fillets and Mince are not to be consumed uncooked. Fish Mince can be used for baby food and for the Elderly who can't chew. Fillets and Mince has a shelf life of 24 months from production date after which consumption could be hazardous.

Construct a Flow diagram: The Team developed and reviewed the flow diagram for fillets and mince to know the possible paths and sequence of the processing steps. A straight line processing steps was adopted for the fillet and mince.

On-site verification of Flow diagram: The team leader along with other team members scrutinized the flow diagram on-site for accuracy and completeness. They verified to confirm with the authentic operations it represents on-site. They checked on-site for the arrangement and positioning of equipment, utensils, workbench, plate freezers, chemicals and additives used in the production process of sole fish fillets and mince.

List all potential hazards, conduct a hazard analysis: Hazard analysis is the most important aspect of the HACCP plan to ensure the safety of the product during and after processing and to improve the shelf life and to make it safe to consume. Hazard analysis was conducted by the HACCP team on the basis of HACCP checklist (as per FAO) and all feasible hazards correlated with the raw material (Sole fish), ingredients, process operations, post process operations were identified and marked as Biological, Chemical and Physical hazards. Hazard identification is beneficial to identify potential biological, chemical and physical hazards that may arise during each step of processing. (Jan T et al, 2016).

Determine the CCPs: The identification of CCPs is a very crucial aspect of the HACCP plan. The CCPs were detected on the basis of decision tree given by Codex Alimentarious Commission.

Establish critical limit for each CCP: For each CCP identified a critical limit was established and specified. A critical limit is a boundary that separates acceptability from unacceptability. When operations are within the limit, the product is safe. Critical limits were set for factors such as time, temperature, chemicals such as chlorine usage, product quantity, product weight etc.

Establish monitoring procedures: Monitoring procedures were established to make sure that the HACCP plan is being followed strictly. Quality assurance officers made sure that the production process is according to the HACCP plan. Time and temperature of the product was being monitored every 30minutes with the use of a food grade thermometer. Raw materials, chemicals, additive usage were checked daily and proper record was documented for future reference and traceability.

Establish corrective action: When monitoring discovers a deviation related to a $\mathrm{CCP}$, corrective actions were carried out to bring the process back to order. This happens when the critical limits associated with a CCP is exceeded.

Establish verification procedure: Verification includes methods, checks, appraisals that ensure compliance with the HACCP plan. Verification was carried out by Quality assurance supervisor through routine and regular checks. Microbiological analysis was also carried out weekly by an in-house microbiologist to ensure Total plate counts of microbes were not exceeded. 
Establish documentation and record keeping: Records are important aspect of the HACCP plan. Written and computerized records to include records generated from the processing procedures were regularly maintained. Other records include raw material, employee hygiene checklist, ingredients traceability, time and temperature, finished products, sanitation, packaging material, microbial, heavy metals records amongst others were kept in compliance with the HACCP plan in the record archives of the company.

Sole fish Fillets: Thawed and De-skinned Cynoglossus browni were filleted with the use of sharp knives on the work bench. The gut, roe and bone (skeletal frame) were separated from the fillets during filleting. Other processes are described in Figure 2.

Sole fish Mince: Bones (skeletal frame) of Cynoglossus browni separated from the fillets during filleting were be-headed, blended and frozen to produce fish mince. Detailed processing steps is described in Figure 3

\subsection{RESULTS AND DISCUSSION}

The HACCP team carefully designed a plan with strict compliance as given by Codex Alimentarius Commission (2003) to achieve safety of sole fish fillets and mince. The CCPs for fillets and mince was agreed on after thorough examination of the process and logically answering the questions as given by the decision tree especially for the fish mince that has two (2) CCPs. Owing to the fact that blending which increases the surface area, texture, appearance, absence of bone and generally the nature of the fish mince are very important, this has led to an increase in the CCP for the fish mince. Cold chain of the processes was maintained at temperatures that will not allow pathogenic bacteria proliferation. The cold chain for the fillets and mince were maintained through the use of ice at each control point (step). Ice will not allow the temperature to exceed limit. The pre-requisite programs such as GMP, SSOP, Pesticide and fumigation program, First-in first-out, training, medical examination for processors etc helped to achieve a safe product. If these programs had gone wrong, the HACCP concept adopted and implemented in the production of frozen sole fish fillets and mince wouldn't have achieved its aim. Sole fish fillets and mince produced are expected to be cooked before consumption as clearly stated in the intended use of the products. The Hazard analysis listed all potential hazards associated with the raw processing of both products as well as measures to prevent these hazards. The frozen products are expected to remain at a cold storage in refrigerator at a temperature of $-18^{0} \mathrm{C}$ knowing fully well that both products has a shelf life of 24 months, though there are still considerations of the Team to reduce the shelf life of Fish mince to 18 months.

The verification report presented by in-house Microbiologist, external analyst and regulatory agencies on finished products proved that the microbial load and heavy metals present in the sample of sole fillets and mince examined were within limits and are fit for export.

\subsection{Challenges in adopting the HACCP Concept}

The challenges faced in the implementation of the HACCP concept are enormous. They include lack of training of personnel, Management irresponsiveness, lack of adequate remuneration, lack of consistent handlers, and lack of Government intervention to encourage the use of safety procedures such as HACCP in food production.

\section{PRODUCTS DESCRIPTION: Deep Frozen Tropical Sole Fillets and Frozen Sole Mince}


International Journal of Food Science

Vol.2, Issue 1. No.1, pp 1- 16, 2019

\section{Origin: Nigeria}

\section{Intended use: Not to be consumed uncooked}

Table 1: Product Description for Sole fish Fillets and Mince (Cynoglossus browni)

\begin{tabular}{|c|c|c|c|}
\hline \multicolumn{2}{|l|}{ Product Name } & Frozen Sole Fillets & Frozen Sole Mince \\
\hline \multirow{3}{*}{\multicolumn{2}{|c|}{$\begin{array}{l}\text { Temperature } \\
\text { Additive } \\
\text { Storage }\end{array}$}} & $-18^{0} \mathrm{C}$ & $-18^{0} \mathrm{C}$ \\
\hline & & Citric Acid E330 & Citric Acid E330 \\
\hline & & 24 hours in Refrigerator & 24 hours in Refrigerator \\
\hline \multicolumn{2}{|l|}{ Expiry Date } & 24 Months from Production date & 24 Months from Production date \\
\hline \multirow{2}{*}{\multicolumn{2}{|c|}{$\begin{array}{l}\text { Packaging } \\
\text { (Certified Food Grade) }\end{array}$}} & $6 \times 2 \mathrm{Kg}$ per Carton & $3 \times 7.5 \mathrm{Kg}$ per Carton \\
\hline & & $\begin{array}{l}\text { Transparent Poly Sheet (LDPE) } \\
\begin{array}{lll}\text { (L) } 31.5 \mathrm{~cm} \text { by } & (\mathrm{w}) 2.3 \mathrm{~cm} \text { of } 6.1 \mathrm{~g} \\
\text { weight } & \end{array}\end{array}$ & $\begin{array}{l}\text { Non-absorbent Polyethylene(PE) } \\
\text { board } 305 \mathrm{gsm},(\mathrm{L}) 51.4 \mathrm{~cm}(\mathrm{~W}) 43.2 \mathrm{~cm} \\
(\mathrm{H}) 6.8 \mathrm{~cm} \text { of } 66 \mathrm{~g} \text { weight }\end{array}$ \\
\hline \multirow[t]{3}{*}{$\begin{array}{l}\text { Nutritional } \\
\text { value/100g }\end{array}$} & $\begin{array}{l}\text { Energy Kcal } \\
\text { Kjoule } \\
\text { Protein }\end{array}$ & $\begin{array}{l}74.1 \\
315 \\
17.8 \%\end{array}$ & $\begin{array}{l}74.1 \\
315 \\
17.8 \%\end{array}$ \\
\hline & $\begin{array}{l}\text { Carbohydrate } \\
\text { (Sugars) } \\
\text { Fat } \\
\text { (of which saturates) }\end{array}$ & $\begin{array}{l}<0.2 \% \\
<0.2 \% \\
0.3 \%\end{array}$ & $\begin{array}{l}<0.2 \% \\
<0.2 \% \\
0.3 \% \\
0.156 \mathrm{~g}\end{array}$ \\
\hline & Salt & $\begin{array}{l}0.156 \mathrm{~g} \\
0.12 \mathrm{~g} \\
\text { Central Eastern Atlantic FAO } 34\end{array}$ & $\begin{array}{l}0.12 \mathrm{~g} \\
\text { Central Eastern Atlantic FAO } 34\end{array}$ \\
\hline
\end{tabular}

\section{Figure 2: Flow diagram for Sole Fillets production}

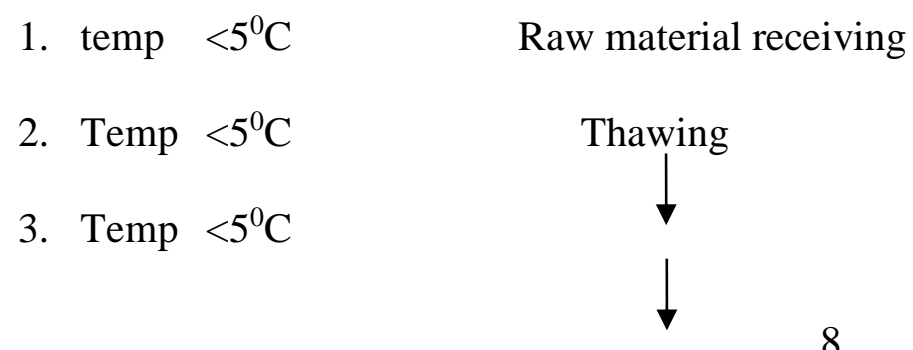


International Journal of Food Science

Vol.2, Issue 1. No.1, pp 1- 16, 2019

4. Deskinning

5. Temp $<5^{0} \mathrm{C}$

6. Temp $<5^{0} \mathrm{C}$

7. Temp $<15^{\circ} \mathrm{C}$

8. Temp $<18^{0} \mathrm{C}$

9. Temp $<18^{0} \mathrm{C}$

10. Temp $<-40^{\circ} \mathrm{C} \mathrm{CCP} 1$

11. Temp $<-18^{0} \mathrm{C}$

12. Temp $<-20^{\circ} \mathrm{C}$

13. Temp $<-20^{\circ} \mathrm{C}$

14. Temp $<-20^{0} \mathrm{C}$

Filleting and Trimming

Figure 3: Flow diagram Sole fish Mince Production

1. Temp $<5^{0} \mathrm{C}$

$2 \quad$ Temp $<5^{0} \mathrm{C}$
Raw material receiving

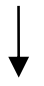

Thawing

$\downarrow$ 
International Journal of Food Science

Vol.2, Issue 1. No.1, pp 1- 16, 2019

$3 \quad$ Temp $<5^{0} \mathrm{C}$

$4 \quad$ Temp $<5^{0} \mathrm{C}$

$5 \quad$ Temp $<5^{0} \mathrm{C}$

$6 \quad$ Temp $<5^{0} \mathrm{C}$

$1.8 \%$ Citric Acid

$7 \quad$ Temp $<15^{\circ} \mathrm{C}$

$8 \quad$ Temp $<15^{\circ} \mathrm{C}$ CCP 1

9 Temp $\quad<15^{\circ} \mathrm{C}$

$10 \quad$ Temp $<18^{0} \mathrm{C}$

11 Temp $-40^{\circ} \mathrm{C} \quad \mathrm{CCP} 2$

12 Temp $-20^{\circ} \mathrm{C}$

13 Temp $-20^{\circ} \mathrm{C}$
De-skinning

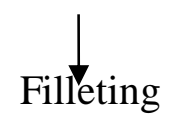

Be-hèading of bone

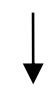

Soak in portable Water and

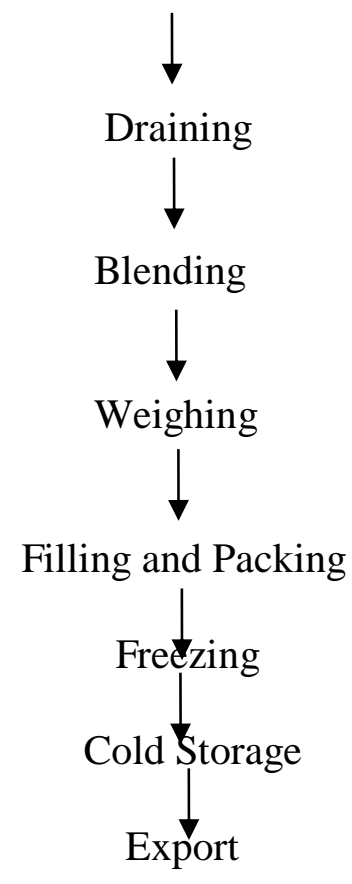

Table 2: Hazard Analysis for Frozen Sole Fish Fillets

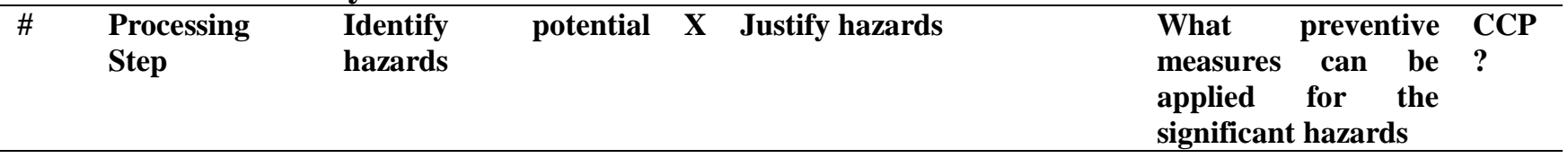


International Journal of Food Science

Vol.2, Issue 1. No.1, pp 1- 16, 2019

\begin{tabular}{|c|c|c|c|c|c|c|c|c|}
\hline \multirow[t]{3}{*}{1} & \multirow{3}{*}{\multicolumn{2}{|c|}{$\begin{array}{l}\text { Raw Material } \\
\text { Receiving }\end{array}$}} & $\begin{array}{l}\text { Biological } \\
\text { Pathogens }\end{array}$ & \multirow{3}{*}{ Marine } & \multirow[t]{2}{*}{$\begin{array}{l}\mathrm{Y} \\
\mathrm{Y}\end{array}$} & \multirow[t]{2}{*}{$\begin{array}{l}\text { Raw Material can be a source } \\
\text { of marine pathogens if fishing } \\
\text { was done in contaminated } \\
\text { fishing grounds }\end{array}$} & $\begin{array}{l}\text { Every lot must be } \\
\text { sampled, tested and } \\
\text { passed } \\
\text { reception. before } \\
\text { fishing in shallow } \\
\text { waters. Source from } \\
\text { approved companies }\end{array}$ & \multirow[t]{2}{*}{ CP1 } \\
\hline & & & Chemical & & & & $\begin{array}{l}\text { Avoid fishing in } \\
\text { polluted areas } \\
\text { Source from only } \\
\text { approved companies }\end{array}$ & \\
\hline & & & Physical & & Y & $\begin{array}{l}\text { Possibility of having damaged } \\
\text { or dehydrated product from } \\
\text { other sources }\end{array}$ & $\begin{array}{l}\text { Every lot must be } \\
\text { sampled } \\
\text { (Organoleptic) before } \\
\text { reception }\end{array}$ & $\mathrm{N}$ \\
\hline \multirow[t]{3}{*}{2} & \multirow{3}{*}{\multicolumn{2}{|c|}{ Thawing }} & Biological & & Y & $\begin{array}{l}\text { Microbial Growth } \\
\text { Contamination by pathogens } \\
\text { due to contact with food } \\
\text { handlers }\end{array}$ & $\begin{array}{l}\text { Temperature/ Time } \\
\text { Control } \\
\text { Controlled by GMP \& } \\
\text { SSOP }\end{array}$ & $\begin{array}{l}\mathrm{CP} 2 \\
\mathrm{~N}\end{array}$ \\
\hline & & & Chemical & & $\mathrm{N}$ & & & $\mathrm{N}$ \\
\hline & & & Physical & & Y & $\begin{array}{l}\text { Presence of particles, Colour } \\
\text { changes }\end{array}$ & & $\mathrm{N}$ \\
\hline \multirow[t]{3}{*}{3} & \multirow{3}{*}{\multicolumn{2}{|c|}{ Deskinning }} & Biological & & Y & $\begin{array}{l}\text { Possible Thermal abuse could } \\
\text { result in pathogenic growth } \\
\text { and possible contamination } \\
\text { through handlers }\end{array}$ & $\begin{array}{l}\text { Time/Temperature } \\
\text { control of filleting } \\
\text { Product to be cooked } \\
\text { before consumption }\end{array}$ & $\begin{array}{l}\mathrm{N} \\
\mathrm{CP} 3\end{array}$ \\
\hline & & & Chemical & & $\mathrm{N}$ & & & $\mathrm{N}$ \\
\hline & & & Physical & & Y & Presence of skin & GMP & $\mathrm{N}$ \\
\hline \multirow[t]{3}{*}{4} & \multirow{3}{*}{\multicolumn{2}{|c|}{$\begin{array}{l}\text { Filleting } \\
\text { Trimming }\end{array}$}} & Biological & & Y & $\begin{array}{l}\text { Microbial Growth } \\
\text { Contamination by pathogens } \\
\text { due to contact with food } \\
\text { handlers }\end{array}$ & GMP & $\begin{array}{l}\mathrm{N} \\
\mathrm{CP} 4\end{array}$ \\
\hline & & & Chemical & & $\mathrm{N}$ & & & $\mathrm{N}$ \\
\hline & & & Physical & & Y & Presence of foreign bodies & GMP & $\mathrm{N}$ \\
\hline \multirow[t]{3}{*}{5} & \multirow{3}{*}{\multicolumn{2}{|c|}{ Washing }} & Biological & & Y & $\begin{array}{l}\text { Temperature abuse and } \\
\text { proliferation }\end{array}$ & $\begin{array}{l}\text { Time/Temperature } \\
\text { control and GMP } \\
\text { Product to be cooked }\end{array}$ & $\begin{array}{l}\mathrm{N} \\
\mathrm{CP5}\end{array}$ \\
\hline & & & Chemical & & Y & Chlorine Concentration & $\begin{array}{l}\text { Correct dosage and } \\
\text { monitoring (Test kit) }\end{array}$ & $\mathrm{N}$ \\
\hline & & & Physical & & Y & $\begin{array}{l}\text { Thermal abuse and microbial } \\
\text { proliferation }\end{array}$ & GMP & $\mathrm{N}$ \\
\hline \multirow[t]{3}{*}{6} & \multirow{3}{*}{\multicolumn{2}{|c|}{ Wrapping }} & Biological & & $\mathrm{Y}$ & $\begin{array}{l}\text { Temperature abuse and } \\
\text { proliferation }\end{array}$ & $\begin{array}{l}\text { Time/Temperature } \\
\text { control and GMP } \\
\text { Product to be cooked }\end{array}$ & CP6 \\
\hline & & & Chemical & & $\mathrm{N}$ & & & $\mathrm{N}$ \\
\hline & & & Physical & & $\mathrm{Y}$ & Presence of foreign body & GMP & $\mathrm{N}$ \\
\hline
\end{tabular}


International Journal of Food Science

Vol.2, Issue 1. No.1, pp 1- 16, 2019

WWW.iprjb.org

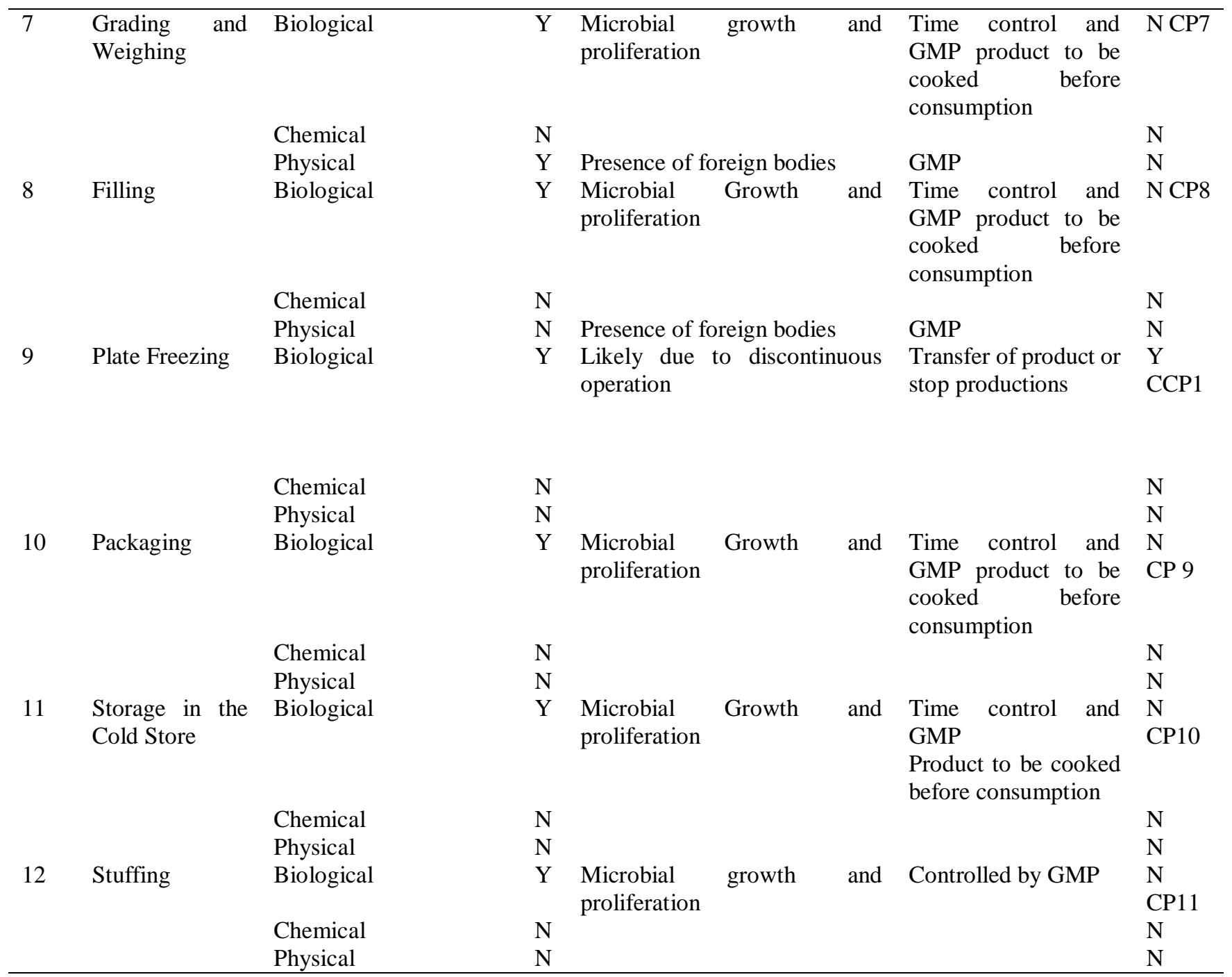

$\mathrm{X}=$ is the potential hazard significant? $\mathrm{N}=\mathrm{No} \mathrm{Y}=\mathrm{Yes}, \mathrm{GMP}=$ Good Manufacturing Practice, $\mathrm{SSOP}=$ Sanitary Standard Operating Procedure, $\mathrm{CCP}=$ Critical Control Point $\mathrm{CP}=$ Control Point.

Table 3: Hazard Analysis for Frozen Sole Fish Mince

\begin{tabular}{lllll}
\hline$\#$ & $\begin{array}{l}\text { Processing } \\
\text { Step }\end{array}$ & $\begin{array}{l}\text { Identify } \\
\text { potential } \\
\text { hazards }\end{array}$ & $X \quad$ Justify hazards & $\begin{array}{l}\text { What preventive measures can be applied } \\
\text { for the significant hazards }\end{array}$ \\
\hline
\end{tabular}


International Journal of Food Science

Vol.2, Issue 1. No.1, pp 1- 16, 2019

\begin{tabular}{|c|c|c|c|c|c|c|}
\hline \multirow[t]{4}{*}{1} & \multirow[t]{4}{*}{$\begin{array}{l}\text { Raw } \\
\text { Material } \\
\text { Receiving }\end{array}$} & $\begin{array}{l}\text { Biological } \\
\text { Marine } \\
\text { Pathogens }\end{array}$ & $\mathrm{Y}$ & \multirow{3}{*}{$\begin{array}{l}\text { Raw Material can be a source of } \\
\text { marine pathogens if fishing was done } \\
\text { in contaminated fishing grounds } \\
\text { Due to oil contamination of some } \\
\text { fishing grounds }\end{array}$} & \multirow{3}{*}{$\begin{array}{l}\text { Every lot must be sampled, tested and passed } \\
\text { before reception. Avoid fishing in shallow } \\
\text { waters. Source from approved companies } \\
\text { Avoid fishing in polluted areas } \\
\text { Source from only approved companies }\end{array}$} & \multirow{3}{*}{$\begin{array}{l}\mathrm{N} \\
\mathrm{CP} 1 \\
\mathrm{~N} \\
\mathrm{CP} 1\end{array}$} \\
\hline & & Chemical & $\mathrm{Y}$ & & & \\
\hline & & & & & & \\
\hline & & Physical & $\mathrm{Y}$ & $\begin{array}{l}\text { Possibility of having damaged or } \\
\text { dehydrated product from other } \\
\text { sources }\end{array}$ & $\begin{array}{l}\text { Every lot must be sampled (Organoleptic) } \\
\text { before reception }\end{array}$ & $\mathrm{N}$ \\
\hline 2 & Thawing & Biological & $\mathrm{Y}$ & Microbial Growth & Temperature/ Time Control & $\mathrm{N}$ \\
\hline & & & & $\begin{array}{l}\text { Contamination by pathogens due to } \\
\text { contact with food handlers }\end{array}$ & Controlled by GMP \& SSOP & CP? \\
\hline & & & & & & $\mathrm{N}$ \\
\hline & & Chemical & $\mathrm{N}$ & & & $\mathrm{N}$ \\
\hline & & Physical & $\mathrm{N}$ & Presence of foreign body & GMP & $\mathrm{N}$ \\
\hline \multirow[t]{5}{*}{3} & Deskinning & Biological & $\mathrm{Y}$ & Possible Thermal abuse could result & Time/Temperature control of filleting & $\mathrm{N}$ \\
\hline & & & & $\begin{array}{l}\text { in pathogenic growth and possible } \\
\text { contamination through handlers }\end{array}$ & Product to be cooked before consumption & \\
\hline & & & & & & $\mathrm{CP} 3$ \\
\hline & & Chemical & $\mathrm{N}$ & & & $\mathrm{N}$ \\
\hline & & Physical & $\mathrm{Y}$ & Presence of skin & GMP & $\mathrm{N}$ \\
\hline \multirow[t]{4}{*}{4} & Filleting & Biological & $\mathrm{Y}$ & Thermal abuse and proliferation & Time/Temperature control and GMP product & $\mathrm{N}$ \\
\hline & & & & & to be cooked before consumption & $\mathrm{CP} 4$ \\
\hline & & Chemical & $\mathrm{N}$ & & & $\mathrm{N}$ \\
\hline & & Physical & $\mathrm{Y}$ & Presence of foreign body & GMP & $\mathrm{N}$ \\
\hline \multirow[t]{4}{*}{5} & Be-Heading & Biological & & Microbial Growth and proliferation & Time control and GMP product to be cooked & $\mathrm{N}$ \\
\hline & & & & & before consumption & CP5 \\
\hline & & Chemical & $\mathrm{N}$ & & & $\mathrm{N}$ \\
\hline & & Physical & $\mathrm{Y}$ & Presence of foreign body & GMP & $\mathrm{N}$ \\
\hline \multirow[t]{3}{*}{6} & Washing & Biological & $\mathrm{Y}$ & Temperature abuse and proliferation & $\begin{array}{l}\text { Time/Temperature control and GMP. Product } \\
\text { to be cooked }\end{array}$ & $\mathrm{N}$ \\
\hline & & Chemical & $\mathrm{Y}$ & Chlorine concentration & Correct damage and monitoring (xxy) & $\mathrm{N}$ \\
\hline & & Physical & $\mathrm{Y}$ & Presence of foreign body & GMP & $\mathrm{N}$ \\
\hline \multirow[t]{4}{*}{7} & Draining & Biological & $\mathrm{Y}$ & Microbial Growth and proliferation & Time control and GMP product to be cooked & $\mathrm{N}$ \\
\hline & & & & & & \\
\hline & & Chemical & $\mathrm{N}$ & & & $\mathrm{N}$ \\
\hline & & Physical & $\mathrm{Y}$ & Presence of foreign body & GMP & $\mathrm{N}$ \\
\hline 8 & Blending & Biological & $\mathrm{Y}$ & Microbial growth and proliferation. & & $\mathrm{Y}$ \\
\hline
\end{tabular}


International Journal of Food Science

Vol.2, Issue 1. No.1, pp 1- 16, 2019

\begin{tabular}{|c|c|c|c|c|c|c|}
\hline & & Chemical & $\mathrm{N}$ & & & $\mathrm{N}$ \\
\hline & & Physical & $\mathrm{Y}$ & Presence of bones & GMP & $\mathrm{N}$ \\
\hline 9 & Weighing & Biological & $\mathrm{Y}$ & Microbial growth and proliferation & $\begin{array}{l}\text { Time control and GMP Product to be cooked } \\
\text { before consumption }\end{array}$ & $\mathrm{CP} 8$ \\
\hline & & Chemical & $\mathrm{N}$ & & & $\mathrm{N}$ \\
\hline & & Physical & $\mathrm{Y}$ & Presence of foreign body & GMP & $\mathrm{N}$ \\
\hline 10 & $\begin{array}{l}\text { Filling and } \\
\text { packing }\end{array}$ & Biological & $\mathrm{Y}$ & Microbial Growth and proliferation & $\begin{array}{l}\text { Time control and GMP Product to be cooked } \\
\text { before consumption }\end{array}$ & $\mathrm{CP} 9$ \\
\hline & & Chemical & $\mathrm{N}$ & & & $\mathrm{N}$ \\
\hline & & Physical & $\mathrm{Y}$ & Presence of foreign body & GMP & $\mathrm{N}$ \\
\hline 11 & $\begin{array}{l}\text { Plate } \\
\text { Freezing }\end{array}$ & Biological & $\mathrm{Y}$ & $\begin{array}{l}\text { Likely due to discontinuous } \\
\text { operation }\end{array}$ & Transfer of product or stop production & $\begin{array}{l}\mathrm{Y} \\
\mathrm{CCP} 2\end{array}$ \\
\hline & & Chemical & $\mathrm{N}$ & & & $\mathrm{N}$ \\
\hline & & Physical & $\mathrm{N}$ & & & $\mathrm{N}$ \\
\hline 12 & $\begin{array}{l}\text { Master } \\
\text { Cartons }\end{array}$ & Biological & Y & Microbial growth and proliferation & $\begin{array}{l}\text { Time control and GMP Product to be cooked } \\
\text { before consumption }\end{array}$ & $\begin{array}{l}\mathrm{N} \\
\mathrm{CP} 10\end{array}$ \\
\hline & & Chemical & $\mathrm{N}$ & & & $\mathrm{N}$ \\
\hline & & Physical & $\mathrm{N}$ & & & $\mathrm{N}$ \\
\hline 13 & $\begin{array}{l}\text { Storage in } \\
\text { the cold } \\
\text { store }\end{array}$ & Biological & $\mathrm{Y}$ & Microbial growth and proliferation & Controlled by GMP & $\begin{array}{l}\mathrm{N} \\
\mathrm{CP} 11\end{array}$ \\
\hline & & Chemical & $\mathrm{N}$ & & & $\mathrm{N}$ \\
\hline & & Physical & $\mathrm{N}$ & & & $\mathrm{N}$ \\
\hline 14 & Stuffing & Biological & $\mathrm{Y}$ & $\begin{array}{l}\text { Possible thermal abuse that could } \\
\text { lead to an elevated number of } \\
\text { pathogens }\end{array}$ & $\begin{array}{l}\text { Temperature control with a recorder } \\
\text { Product to be cooked before consumption }\end{array}$ & $\mathrm{CP} 12$ \\
\hline & & Chemical & $\mathrm{N}$ & & & $\mathrm{N}$ \\
\hline & & Physical & $\mathrm{N}$ & & & $\mathrm{N}$ \\
\hline
\end{tabular}

$\mathrm{X}=$ is the potential hazard significant? $\mathrm{N}=$ No $\mathrm{Y}=\mathrm{Yes}$, GMP= Good Manufacturing Practice, $\mathrm{SSOP}=$ Sanitary Standard Operating Procedure, $\mathrm{CCP}=$ Critical Control Point $\mathrm{CP}=$ Control Point

\section{Table 4: HACCP Plan for the Critical Control Point of Sole fish Fillets}

\begin{tabular}{llllll}
\hline CCP Hazard & $\begin{array}{l}\text { Control } \\
\text { Measure }\end{array}$ & $\begin{array}{l}\text { Critical } \\
\text { Limit }\end{array}$ & Monitoring & \multicolumn{2}{c}{$\begin{array}{l}\text { Correcti Verification } \\
\text { ve } \\
\text { Action }\end{array}$} \\
& & What & Who Frequency How & \multicolumn{2}{c}{ How } \\
\hline
\end{tabular}


International Journal of Food Science

Vol.2, Issue 1. No.1, pp 1- 16, 2019

WWW.iprjb.org

\begin{tabular}{|c|c|c|c|c|c|c|c|c|}
\hline $\begin{array}{l}\text { Freezin } \\
\mathrm{g}\end{array}$ & $\begin{array}{l}\text { Biological } \\
\text { : } \\
\text { Microbial } \\
\text { growth } \\
\text { and } \\
\text { proliferati } \\
\text { on }\end{array}$ & $\begin{array}{l}\text { Pre-cooled } \\
\text { plate freezer } \\
\text { and } \\
\text { continuous } \\
\text { freezing at - } \\
40^{\circ} \mathrm{C} \text { for } \\
3 \mathrm{hrs}\end{array}$ & $\begin{array}{l}\text { Core } \\
\text { temperat } \\
\text { ure }-20^{\circ} \mathrm{C}\end{array}$ & $\begin{array}{l}\text { Temperatur } \\
\text { e gauge } \\
\text { check, core } \\
\text { temperature } \\
\text { of the } \\
\text { product and } \\
\text { visual } \\
\text { inspection }\end{array}$ & $\begin{array}{l}\text { Quality } \\
\text { Control } \\
\text { Supervisors, } \\
\text { Production } \\
\text { Supervisor } \\
\text { and } \\
\text { Refrigerator } \\
\text { Engineer }\end{array}$ & $\begin{array}{l}\text { Every } \\
\text { discharge }\end{array}$ & $\begin{array}{l}\text { Call the } \\
\text { attention } \\
\text { of the } \\
\text { Ref. } \\
\text { Engineer }\end{array}$ & $\begin{array}{l}\text { Organoleptic } \\
\text { analysis of } \\
\text { finished } \\
\text { product by in- } \\
\text { house } \\
\text { microbiologist } \\
\text { s, external } \\
\text { analyst \& } \\
\text { regulatory } \\
\text { agencies } \\
\text { report. }\end{array}$ \\
\hline
\end{tabular}

Table 5: HACCP Plan for the Critical Control Point of Sole fish Mince

\begin{tabular}{|c|c|c|c|c|c|c|c|c|c|}
\hline \multirow[t]{2}{*}{ CCP } & \multirow[t]{2}{*}{ Hazard } & \multirow{2}{*}{$\begin{array}{l}\text { Control } \\
\text { Measure }\end{array}$} & \multirow{2}{*}{$\begin{array}{l}\text { Critical } \\
\text { Limit }\end{array}$} & \multicolumn{4}{|c|}{ Monitoring } & \multirow{2}{*}{$\begin{array}{l}\text { Corrective } \\
\text { Action }\end{array}$} & \multirow[t]{2}{*}{ Verification } \\
\hline & & & & What & Who & Frequency & How & & \\
\hline Blending & $\begin{array}{l}\text { Biological: } \\
\text { Microbial } \\
\text { growth and } \\
\text { proliferation }\end{array}$ & $\begin{array}{l}\text { Increase } \\
\text { speed and } \\
\text { GMP }\end{array}$ & $\begin{array}{l}<5 \text { minutes } \\
\text { to blend } \\
5 \mathrm{~kg} \text { of Sole } \\
\text { bone at } \\
<15^{\circ} \mathrm{C}\end{array}$ & $\begin{array}{l}\text { Blending of } \\
\text { sole bone. } \\
\text { Check } \\
\text { temperature }\end{array}$ & $\begin{array}{l}\text { Quality } \\
\text { Control } \\
\text { Supervisors }\end{array}$ & $\begin{array}{l}\text { Every } 30 \\
\text { minutes }\end{array}$ & $\begin{array}{l}\text { Use of a } \\
\text { blender. } \\
\text { Thermometer }\end{array}$ & $\begin{array}{l}\text { When } \\
\text { temperature } \\
\text { or time } \\
\text { exceed } \\
\text { critical } \\
\text { limit, } \\
\text { increase } \\
\text { speed }\end{array}$ & $\begin{array}{l}\text { Organoleptic } \\
\text { analysis of } \\
\text { finished product } \\
\text { by in-house } \\
\text { microbiologists, } \\
\text { external analyst } \\
\& \text { regulatory } \\
\text { agencies report. }\end{array}$ \\
\hline Freezing & $\begin{array}{l}\text { Biological: } \\
\text { Microbial } \\
\text { growth and } \\
\text { proliferation }\end{array}$ & $\begin{array}{l}\text { Pre-cooled } \\
\text { plate } \\
\text { freezer and } \\
\text { continuous } \\
\text { freezing at } \\
-40^{\circ} \mathrm{C} \text { for } \\
3 \mathrm{hrs}\end{array}$ & $\begin{array}{l}\text { Core } \\
\text { temperature } \\
-20^{\circ} \mathrm{C}\end{array}$ & $\begin{array}{l}\text { Temperature } \\
\text { gauge check, } \\
\text { core } \\
\text { temperature } \\
\text { of the } \\
\text { product and } \\
\text { visual } \\
\text { inspection }\end{array}$ & $\begin{array}{l}\text { Quality } \\
\text { Control } \\
\text { Supervisors, } \\
\text { Production } \\
\text { Supervisor } \\
\text { and } \\
\text { Refrigerator } \\
\text { Engineer }\end{array}$ & $\begin{array}{l}\text { Every } \\
\text { discharge }\end{array}$ & Thermometer & $\begin{array}{l}\text { Call the } \\
\text { attention of } \\
\text { the Ref. } \\
\text { Engineer }\end{array}$ & $\begin{array}{l}\text { Organoleptic } \\
\text { analysis of } \\
\text { finished product } \\
\text { by in-house } \\
\text { microbiologists, } \\
\text { external analyst } \\
\& \text { regulatory } \\
\text { agencies report. }\end{array}$ \\
\hline
\end{tabular}

\subsection{CONCLUSION AND RECOMMENDATIONS}

\section{Conclusions}

The HACCP concept focused on the safety of sole fish fillets and mince through a systematic and scientific approach to hazard identification, assessment and control. Preventive and control measures in dealing with identified hazards helps to eliminate or reduce hazards to acceptable levels. Pre-requisite programs consolidate the effectiveness of the HACCP in achieving safety of food products. The verification exercise confirmed that the HACCP concept implemented in the processing of Sole fish fillets and mince was adhered to and the products are safe, fit for consumption and ready for export.

\section{Recommendations}


To achieve safety of food products requires the joint effort of the HACCP team. Hence, adequate training of the team members on recent developments and changes in the food industry is very key to consistently improve efforts to always maintain the quality brand the product is known for. In Nigeria's Fisheries subsector, workers are not well paid and this affects the workers' productivity. Government should look into the issue of expatriates coming into the country to do jobs that Nigerian citizens can effectively do. The overhead cost on these expatriates increases the cost of processing and production. Awareness of the role of HACCP to achieving safety of food products should be increased so that intending food organizations would see the concept as a necessity.

\section{REFERENCES}

CAC (2003). Guidelines for the Application of the Hazard Analysis Critical Control Point (HACCP) system. Codex Alimentarious Commission, FAO, Rome.

FAO (1997) Food and Agricultural Organisation. Hazard Analysis And Critical Control Point (HACCP) System and Guidelines For its Application.Annex to CAC/RCP 1-1969, Rev 3. www.fao.org

Georgia P. Grintzali and Fotoula Babatsikou (2010). The significance of the application of Hazard Analysis Critical Control Point System in hospital catering. Health science Journal pp:84-93 . EISSN: 1791-809X

Jan T, Yadav KC and Borude S (2016). Study of HACCP implementation in Milk Processing Plant at Khyber Agro Pvt. Ltd in Jammu \& Kashmir. J Food Process Technol 7:610. doi: 10.4172/21577110.1000610

Marine Species Identification portal (2018). Fishes of the NE Atlantic and the Mediterranean. Nigerian tongue sole (Cynoglossus browni) 